\title{
Hubungan antara Konsep Diri, Regulasi Diri dan Tingkat Religiusitas dengan Penyesuaian Diri pada Santri Pondok Pesantren Al-Berr Pasuruan
}

\section{The Correlation Between Self-Concept, Self-Regulation and Level of Religiusity Toward Personal Adjustment Student of Pondok Al-Berr Pasuruan}

\author{
Agus Poerwanto ${ }^{1}$, Hetty Murdiyani ${ }^{1}$ \\ ${ }^{1}$ Fakultas Psikologi Universitas Muhammadiyah Surabaya \\ aguspoerwanto@yahoo.com
}

\begin{abstract}
Abstrak
Tujuan penelitian ini adalah untuk mengetahui hubungan antara konsep diri, regulasi diri dan tingkat religiusitas dengan penyesuaian diri pada santri Pondok Pesantren Al Berr Pasuruan. Penelitian ini dilakukan pada santri baru Pondok Pesantren Al-Berr dengan jumlah sampel sebanyak 80 orang yang dipilih menggunakan teknik purposive random sampling. Alat pengumpulan data menggunakan kuesioner model skala Likert yang terdiri dari skala konsep diri, skala regulasi diri, skala tingkat religiusitas dan skala penyesuaian diri. Metode analisis data menggunakan teknik analisis regresi berganda. Berdasarkan hasil analisis dengan satu variabel terikat yaitu penyesuaian diri dan tiga variabel bebas yaitu konsep diri, regulasi diri, dan tingkat religiusitas diperoleh nilai $\mathrm{F}=15.358$, dengan nilai $\operatorname{Rx}_{1} \mathrm{x}_{2} \mathrm{X}_{3}$ sebesar 0,614 dan nilai $\mathrm{p}=0,000(\mathrm{p}<0,05)$ maka dapat disimpulkan bahwa ada hubungan yang signifikan konsep diri, regulasi diri, tingkat religiusitas dengan penyesuaian diri pada santri pondok pesantren Al Berr Pasuruan.
\end{abstract}

Kata kunci: konsep diri, regulasi diri, religiusitas, penyesuaian diri, santri.

\begin{abstract}
This study aims to determine the correlation between self-concept, self-regulation and religiosity with adjustment at students of Al Berr Islamic Boarding School Pasuruan. This research was conducted in student at Al-Berr Islamic Boarding School with 80 people selected using purposive random sampling technique. The data collection tool used a Likert scale model questionnaire consisting of a self-concept scale, self-regulation scale, religiosity level scale and adjustment scale. Methods of data analysis using multiple regression analysis techniques. Based on the results of the analysis with one dependent variable, namely adjustment and three independent variables, namely self-concept, self-regulation, and the level of religiosity, $F=15.358$, with an $R x_{1} x_{2} X_{3}$ value of 0.614 and $p$ value $=0.000$ ( $\left.p<0.05\right)$, it can be concluded that there is a significant relationship of self-concept, self-regulation, level of religiosity with adjustment at the Al Berr Pasuruan Islamic boarding school students.
\end{abstract}

Keywords: self concept, self regulation, religiosity, personal adjustment, student

\section{Pendahuluan}

Dunia pendidikan formal pada era modern tidak hanya menawarkan pendidikan yang bersifat umum namun juga menawarkan pendidikan berbasis keagamaan khususnya agama Islam. Pondok Pesantren merupakan salah satu lembaga pendidikan berbasis keagamaan yang mempunyai kekhasan tersendiri yang berbeda dengan lembaga pendidikan lainnya. Berdasarkan asal katanya, pondok pesantren mempunyai pengertian yaitu tempat atau kompleks para santri untuk belajar atau mengaji 
ilmu pengetahuan agama kepada seorang guru yang biasa disebut sebagai kiai. Biasanya tempat atau komplek tersebut berbentuk asrama atau kamar-kamar kecil dengan bangunan yang sederhana dan cenderung apa adanya. Pendidikan yang didapat di pesantren terdiri dari pendidikan berbasis Islam, pengajaran cara berdakwah, pengembangan kehidupan bermasyarakat dan pendidikan lainnya yang sejenis. Kedudukan pondok pesantren dalam sistem pendidikan Indonesia telah diatur dalam UU Sisdiknas No. 20 Tahun 2003 tentang pendidikan keagamaan pasal 30 yaitu pendidikan keagamaan berbentuk pendidikan diniyah, pesantren, pasraman, pabhaja samanera, dan bentuk lain yang sejenis (ayat 4), serta dapat diselenggarakan pada jalur formal, nonformal, dan informal (ayat 3) (www.kemenag.go.id).

Siswa yang belajar di pondok pesantren disebut sebagai santri. Sama halnya dengan sekolah pada umumnya, pondok pesantren juga menerima santri baru. Santri yang belajar di sebuah pondok pesantren pada dasarnya tidak hanya berasal dari daerah yang sana dengan pondok pesantren tersebut berdiri, akan tetapi juga berasal dari luar kota dan bahkan ada santri yang berasal dari luar provinsi. Setiap santri yang berasal dari berbagai wilayah yang berbeda tersebut secara otomatis akan menempati tempat tinggal baru di dalam pondok pesantren yang tentunya akan jauh berbeda dengan tempat tinggal sebelumnya dan diharuskan untuk hidup bersama-sama dengan para santri lainnya dengan perbedaan latar belakang ekonomi, sosial, budaya dan tempat tinggal. Seorang individu yang menjalani kehidupan di pondok pesantren, maka akan merasakan berada dalam situasi atau kondisi yang sangat berbeda dengan saat berada di rumah. Kondisi yang jauh dari orang tua, jadwal kegiatan belajar yang sangat padat dari mulai bangun tidur hingga waktu tidur kembali, disamping juga hidup bersama dengan orang-orang baru yang memiliki latar belakang yang bermacam-macam tentunya akan menimbulkan problem tersendiri pada diri setiap individu. Ditambah lagi terdapat fenomena bahwa tidak semua santri mempunyai motivasi pribadi untuk belajar di pondok pesantren. Ada banyak kasus bahwa justru orang tua yang berkeinginan untuk memasukkan anak ke dalam pondok pesantren. Oleh karena itu tidak mengherankan jika kemudian terdapat beberapa anak yang tidak mampu beradaptasi, merasa tidak kerasan sehinggapada akhirnya memilih untuk pulang kerumah dan tidak kembali lagi ke pondok.

Beberapa fenomena yang menunjukkan kegagalan santri dalam penyesuaian diri di lingkungan pondok pesantren, diantaranya seperti yang disampaikan Nyai Hj Mundjidah Wahab pada kegiatan halal bi halal di Madrasah Aliyah Unggulan KH Abdul Wahab Hasbulloh Tambak Beras, Jombang, Jawa Timur pada Sabtu 29 Juni 2019 (nu.or.id). Wali santri datang ke pesantren bukan hanya untuk mengunjungi anak yang belajar, namun justru banyak yang berniat mengambil kembali putra atau putrinya dikarenakan tidak kerasan belajar di pondok. Fenomena tentang ketidakmampuan santri dalam menyesuaikan diri juga ditemukan di Pondok Pesantren Al-Amien Putra, dimana pada kelas santri baru di tahun 2019, berdasarkan keterangan ketua shof kelas 1 Reguler Putra sebanyak 27 santri tidak kembali setelah pulang ke rumahnya pasca liburan maulid nabi. Dari jumlah keseluruhan 330 santri pada jenjang kelas 1, santri yang kembali ke pondok setelah liburan maulid berjumlah 303 santri. Menurut pengurus pesantren Al-Amien Putra, fenomena berkurangnya jumlah santri yang kembali ke pondok mengindikasikan bahwa ada beberapa santri yang kurang mampu menyesuaikan diri. Hal ini biasanya didahului dengan beberapa perilaku yang memperkuat gejala ketidakmampuan beradaptasi, antara lain seperti sering dikamar dan jarang bergaul, lebih suka menyendiri, sering melamun dan terkadang menangis, sering tidak makan, diam dan kurang merespon orang lain baik guru maupun teman, tidak mengikuti pelajaran dikelas atau tidak memperhatikan guru, tidak punya minat, tidak berpartisipasi dalam kelompok. Hal inipun terjadi pada santri baru yang menjalani pendidikan di Pondok Pesantren Al Berr Pasuruan. Santri baru yang dimaksud disini adalah santri yang baru saja mendaftar ke pondok baik pada jenjang pendidikan SMP maupun jenjang pendidikan SMA.

Setiap santri yang menjalani pendidikan di pondok pesantren mutlak membutuhkan kesiapan pribadi untuk dapat menyesuaikan diri dengan lingkungan pondok. Calhoun \& Acocella (2010) mengemukakan bahwa penyesuaian diri merupakan interaksi yang dilakukan oleh seseorang secara kontinyu dengan dirinya sendiri, dengan orang lain, dan dengan lingkungan disekitarnya. Schneider (1964) mengemukakan individu bisa dikatakan memiliki penyesuaian diri yang baik apabila individu tersebut mampu mengubah diri dengan menunjukkan respon-respon mental dan perilaku yang diharapkan bisa sesuai dan selaras dengan keinginan atau tuntutan lingkungan yang dibebankan terhadap individu agar dapat terhindar dari masalah ataupun konflik (dalam Asrori \& Ali, 2006). Schneider menyebutkan ada lima faktor yang mempengaruhi penyesuaian diri, diantaranya yaitu: kondisi fisik (hereditas dan konstitusi fisik, sistem tubuh, kesehatan fisik), kepribadian (kemauan dan 
kemampuan untuk berubah, regulasi diri/self regulation, self realization, intelegensi), proses belajar (belajar, pengalaman, latihan, desterminasi diri), lingkungan (lingkungan keluarga, sekolah, masyarakat), agama dan budaya (adaptive, adjustive). Salah satu faktor yang mempengaruhi penyesuaian diri pada santri adalah konsep diri yang dimilikinya. Selain itu meliputi kelebihankelebihan yang dimiliki oleh dirinya, dan juga kekurangan atau kegagalan dirinya. Menurut Bandura faktor lain yang mempengaruhi penyesuaian diri adalah regulasi diri (dalam Widjaja, 2014). Tingkat religiusitas yang dimiliki oleh santri juga menjadi faktor yang mempengaruhi penyesuaian dirinya (Jalaluddin, 2012).

Konsep diri adalah suatu pandangan atau keyakinan diri terhadap keseluruhan diri, baik yang menyangkut kelebihan ataupun kekurangan diri, sehingga mempunyai sebuah pengaruh yang besar terhadap keseluruhan perilaku yang ditampilkan (Baron dan Byrne, 2004). Menurut Hurlock (dalam Nurhasyanah, 2012), seseorang yang memiliki konsep diri negatif dirinya merasa tidak mampu, raguragu dan rendah diri, sehingga menimbulkan penyesuaian diri yang buruk. Menurut Ghufron \& Risnawita (2014), regulasi diri berkaitan dengan pembangkitan diri baik pikiran, perasaan serta tindakan yang direncanakan dan adanya timbal balik yang disesuaikan pada pencapaian tujuan personal.. Menurut Pintrich (2003), seorang santri yang mampu melakukan regulasi diri dalam belajar adalah seeseorang yang menetapkan tujuan dan merencanakan kegiatannya, melakukan monitor dan kontrol terhadap aspek kognitif, motivasi serta tingkah lakunya dalam mencapai tujuan tersebut. Tingkat religiusitas yang dimiliki oleh santri juga menjadi faktor yang mempengaruhi penyesuaian dirinya. Jalaluddin (2012) mengatakan bahwa religiusitas adalah kemampuan yang dimiliki individu dalam memahami, menghayati, serta mengaplikasikan nilai-nilai agama yang dianutnya dalam kehidupan sehari-hari. Konflik, frustasi dan ketegangan psikis yang lain dapat berkurang dengan adanya religiuitas, karena religiusitas dapat memberikan suasana psikologis. Religiusitas memberikan nilai, keyakinan dan praktik-praktik sehingga individu memiliki arti yang mendalam, tujuan dan stabilitas hidup yang digunakan dalam menghadapi tuntutan dan perubahan yang terjadi dalam hidupnya.

Dari uraian latar belakang tersebut diatas maka tujuan dari penelitian ini adalah untuk mengetahui hubungan antara konsep diri, regulasi diri dan tingkat religiusitas dengan penyesuaian diri pada santri Pondok Pesantren Al Berr Pasuruan, dengan hipotesis penelitian sebagai berikut :

1. Ha : Ada hubungan antara konsep diri, regulasi diri dan tingkat religiusitas dengan penyesuaian diri pada santri Pondok Pesantren Al Berr Pasuruan

2. Ho : Tidak ada hubungan antara konsep diri, regulasi diri dan tingkat religiusitas dengan penyesuaian diri pada santri Pondok Pesantren Al Berr Pasuruan.

\section{Metode Penelitian}

Penelitian ini merupakan penelitian kuatitatif dengan desain koresional, melibatkan dua jenis variabel, yaitu variabel bebas dan variabel terikat yaitu: konsep diri $\left(\mathrm{V}_{\mathrm{x} 1}\right)$, regulasi diri $\left(\mathrm{V}_{\mathrm{x} 2}\right)$, religiusitas $\left(\mathrm{V}_{\mathrm{x} 3}\right)$, penyesuaian diri $\left(\mathrm{V}_{\mathrm{y}}\right)$. Populasi dalam penelitian ini adalah santri di Pondok Pesantren $\mathrm{Al}$ Berr Sangarejo Pasuruan dengan sampel sebanyak 80 orang yang dipilih berdasarkan teknik purposive random sampling. Data penelitian diambil dengan menggunakan kuesioner model skala Likert dengan empat pilihan jawaban, antara lain yaitu skala konsep diri, skala regulasi diri, skala tingkat religiusitas dan skala penyesuaian diri. Metode analisis data menggunakan teknik analisis regresi berganda.

\section{Hasil Penelitian}

Hasil pengujian daya diskriminasi aitem terhadap alat ukur skala yang digunakan dalam penelitian ini dianalisis dengan menggunakan teknik korelasi Product Moment Pearson. Skala konsep diri yang disusun berdasarkan aspek konsep diri menurut Berzonsky (fisik, psikis, social dan moral) didapatkan hasil 15 aitem valid. Skala regulasi diri yang disusun berdasarkan aspek regulasi diri menurut Zimmerman (dalam Ghufron \& Risnawati, 2014) yaitu metakognitif, motivasi dan perilaku diperoleh 15 aitem valid. Penyusunan skala tingkat religiusitas yang didasarkan pada dimensi religiusitas menurut Glock \& Stark (dalam Ancok \& Suroso, 1994), yaitu: keyakinan, praktik ibadah, penghayatan, pengetahuan agama dan pengamalan didapatkan 15 item valid. Sementara skala penyesuaian diri disusun dengan menggunakan aspek menurut Runyon dan Haber (dalam Sitorus \& Warsito, 2013) yaitu persepsi terhadap realita, kemampuan untuk mengatasi stress dan kecemasan, 
gambaran diri yang positif, kemampuan untuk mengekspresikan emosi dengan baik dan hubungan interpersonal yang baik, menghasilkan 15 aitem valid.

Reliabilitas adalah indeks yang menunjukan sejauh mana alat ukur dapat dipercaya atau dapat diandalkan. Teknik uji reliabilitas dalam penelitian ini menggunakan metode Alpha Cronbach's. Hasil pengujian reliabilitas Cronbach alpha didapatkan nilai 0,863 (skala konsep diri), 0.908 (skala regulasi diri), 0.917 (skala tingkat religiusitas) dan 0.884 (skala penyesuaian diri). Oleh karena standar minimal untuk pengujian reliabilitas menggunakan acuan angka $r$ kritis $\geq 0,6$, maka keempat alat ukur skala tersebut dinyatakan reliabel.

Analisis data penelitian dengan menggunakan teknik analisis regresi berganda mensyaratkan adanya pemenuhan asumsi regresi. Oleh karena itu terlebih dahulu dilakukan uji normalitas dan uji linieritas data. Berdasarkan pengujian normalitas data, didapatkan hasil perhitungan seperti dalam tabel berikut ini :

Tabel 1. Hasil Uji Normalitas Data

\begin{tabular}{llrrrr}
\hline \multicolumn{5}{c}{ One-Sample Kolmogorov-Smirnov Test } \\
\hline $\mathrm{N}$ & & Penyesuaian Diri & Konsep Diri & Regulasi Diri & Religiusitas \\
\cline { 3 - 6 } Normal & Mean & 80 & 80 & 80 & 80 \\
Parameters & & 50.90 & 50.28 & 51.51 & 51.10 \\
& Std. & 6.789 & 6.957 & 6.288 & 6.659 \\
& Deviation & .101 & .114 & .110 & .131 \\
Most Extreme & Absolute & .090 & .081 & .089 & .091 \\
Differences & Positive & -.101 & -.114 & -.110 & -.131 \\
& Negative & .904 & 1.019 & .988 & 1.171 \\
\multicolumn{2}{l}{ Kolmogorov-Smirnov Z } & .388 & .250 & .284 & .129 \\
Asymp. Sig. (2-tailed) & & &
\end{tabular}

a. Test distribution is Normal.

Berdasarkan tabel uji normalitas dengan menggunakan Kolmogorov-Smirnov didapatkan nilai signifikasi pada tabel 1 sebesar 0.250 untuk variabel konsep diri, 0.284 untuk variabel regulasi diri, 0.129 untuk variabel tingkat religiusitas dan 0.388 untuk variabel penyesuaian diri. Hasil ini memiliki nilai lebih besar dari nilai signifikasi 5\% (0.05), maka dapat disimpulkan bahwa data variabel regulasi diri dan penyesuaian diri memiliki distribusi normal.

Berdasarkan pengujian linieritas data, didapatkan hasil perhitungan seperti dalam tabel 2 . Berdasarkan tabel 2 hasil uji linearitas data variabel konsep diri dan variabel penyesuaian diri menunjukkan nilai signifikansi sebesar 0.066. Nilai signifikansi pada variabel regulasi diri dan variabel penyesuaian diri sebesar 0.107 dan sebaran data variabel tingkat religiusitas dan variabel penyesuaian diri menunjukkan nilai signifikasi 0.306. Ketiga nilai signifikansi tersebut menunjukan bahwa data tergolong linear. 
Tabel 2. Hasil Uji Linieritas Data

\begin{tabular}{|c|c|c|c|c|c|c|}
\hline \multirow{7}{*}{$\begin{array}{l}\text { Penyesuaian } \\
\text { Diri * Konsep } \\
\text { Diri }\end{array}$} & & \multicolumn{5}{|l|}{ ANOVA Table } \\
\hline & & $\begin{array}{c}\text { Sum of } \\
\text { Squares }\end{array}$ & $\mathrm{df}$ & $\begin{array}{l}\text { Mean } \\
\text { Square }\end{array}$ & $\mathrm{F}$ & Sig. \\
\hline & (Combined) & 1981.221 & 22 & 90.056 & 3.092 & .000 \\
\hline & Linearity & 963.226 & 1 & 963.226 & 33.075 & .000 \\
\hline & $\begin{array}{l}\text { Deviation from } \\
\text { Linearity }\end{array}$ & 1017.995 & 21 & 48.476 & 1.665 & .066 \\
\hline & Within Groups & 1659.979 & 57 & 29.122 & & \\
\hline & Total & 3641.200 & 79 & & & \\
\hline \multirow{5}{*}{$\begin{array}{l}\text { Penyesuaian } \\
\text { Diri * Regulasi } \\
\text { Diri }\end{array}$} & (Combined) & 1951.139 & 22 & 88.688 & 2.991 & .000 \\
\hline & Linearity & 1005.234 & 1 & 1005.234 & 33.903 & .000 \\
\hline & $\begin{array}{l}\text { Deviation from } \\
\text { Linearity }\end{array}$ & 945.905 & 21 & 45.043 & 1.519 & .107 \\
\hline & Within Groups & 1690.061 & 57 & 29.650 & & \\
\hline & Total & 3641.200 & 79 & & & \\
\hline \multirow{5}{*}{$\begin{array}{l}\text { Penyesuaian } \\
\text { Diri * } \\
\text { Religiusitas }\end{array}$} & (Combined) & 1509.156 & 22 & 68.598 & 1.834 & .035 \\
\hline & Linearity & 585.194 & 1 & 585.194 & 15.645 & .000 \\
\hline & $\begin{array}{l}\text { Deviation from } \\
\text { Linearity }\end{array}$ & 923.962 & 21 & 43.998 & 1.176 & .306 \\
\hline & Within Groups & 2132.044 & 57 & 37.404 & & \\
\hline & Total & 3641.200 & 79 & & & \\
\hline
\end{tabular}

Analisis uji hubungan antara variabel bebas dan variabel terikat dapat diketahui dari hasil signifikasi setelah dilakukan pengujian regresi berganda. Berdasarkan pengolahan data diperoleh hasil uji regresi berganda seperti dalam tabel berikut ini :

Tabel 3 Hasil Perhitungan Uji Regresi Berganda

\begin{tabular}{lrrrr}
\hline \multicolumn{5}{c}{ Model Summary } \\
\hline Model & $\mathrm{R}$ & $\mathrm{R}$ Square & Adjusted R Square & $\begin{array}{r}\text { Std. Error of the } \\
\text { Estimate }\end{array}$ \\
\hline 1 & $.614^{\mathrm{a}}$ & .377 & .353 & 5.461 \\
\hline
\end{tabular}

a. Predictors: (Constant), religiusitas, regulasi_diri, konsep_diri

\begin{tabular}{lrrrrrr}
\hline \multicolumn{7}{c}{ ANOVAb } \\
\hline Model & & Sum of Squares & df & Mean Square & F & Sig. \\
\hline 1 & Regression & 1374.295 & 3 & 458.098 & 15.358 & $.000^{\text {a }}$ \\
& Residual & 2266.905 & 76 & 29.828 & & \\
& Total & 3641.200 & 79 & & & \\
\hline
\end{tabular}

a. Predictors: (Constant), Religiusitas, Regulasi Diri, Konsep Diri

b. Dependent Variable: Penyesuaian Diri

Dari tabel diatas dapat diketahui bahwa hasil uji regresi linier berganda pada satu variabel terikat yaitu penyesuaian diri dan tiga variabel bebas yaitu konsep diri, regulasi diri, dan tingkat 
religiusitas diperoleh nilai $\mathrm{F}$ sebesar 15.358 dengan nilai $\mathrm{Rx}_{1} \mathrm{x}_{2} \mathrm{x}_{3}$ sebesar 0,614 dan nilai $\mathrm{p}=0,000$ $(\mathrm{p}<0,05)$ maka hal ini berarti Ha diterima dan Ho ditolak, sehingga dapat disimpulkan ada hubungan yang signifikan antara konsep diri, regulasi diri, tingkat religiusitas dengan penyesuaian diri pada santri pondok pesantren Al Berr Pasuruan.

\section{Pembahasan}

Hasil analisis pada penelitian dapat disimpulkan bahwa hubungan antara variabel konsep diri, regulasi diri, tingkat religiusitas dan penyesuaian diri positif yaitu semakin tinggi konsep diri, regulasi diri, dan tingkat religiusitas pada santri maka semakin tinggi penyesuaian diri santri. Sebaliknya, semakin rendah $\mathrm{r}$ konsep diri, regulasi diri, dan tingkat religiusitas pada santri maka semakin rendah penyesuaian diri dirinya. Hal tersebut sesuai dengan pendapat Siregar (2003) bahwa diri pribadi yang mencakup komponen konsep diri, harga diri, percaya diri, dan regulasi diri berpengaruh terhadap penyesuaian diri mahasiswa di kehidupan sosial abad 21.

Konsep diri santri sebagaimana yang digambarkan oleh Berzonsky (1981) dapat dilihat dari penilaian santri terhadap diri sendiri yang meliputi penilaian atas pemikiran, perasaan dan sikap pribadi, penilaian santri akan peran sosial yang melekat pada diri serta penilaian akan prinsip-prinsip yang memberikan arah bagi kehidupan santri tersebut. Proses pembentukan konsep diri yang dimulai dari kehidupan masa kecil terus berkembang hingga masa kini dan dapat berubah baik disadari maupun tidak oleh individu, bisa berkembang kearah positif maupun negatif. Santri yang memiliki konsep diri positif akan terlihat percaya diri, memiliki penerimaan diri yang baik, optimis, harga diri tinggi dan mempunyai perasaan aman. Sebaliknya santri yang memiliki konsep diri negatif akan menarik diri dari lingkungan dalam hal ini lingkungan pergaulan di pondok, pesimis, harga diri rendah, merasa tidak aman dan cenderung peka terhadap kritikan, sehingga pada akhirnya kurang dapat menyesuaikan diri dengan tuntutan lingkungan dan sosial di pondok pesantren.

Regulasi diri turut mempengaruhi penyesuaian diri individu. Hal ini dibahas oleh Miller \& Brown (dalam Neal \& Carey, 2005) yang mengemukakan bahwa regulasi diri adalah kemampuan yang dipunyai individu untuk membuat perencanaan, memberikan pengarahan, dan pengamatan perilaku agar dapat mendekati tujuan tertentu dengan mengikutsertakan komponen fisik, kognitif, emosional dan sosial. Kemampuan individu untuk melakukan regulasi diri perlu dikembangkan agar dapat membantu individu mengatasi berbagai situasi menekan. Dalam proses regulasi diri, individu mengetahui permasalahan dari dalam diri individu maupun dari luar. Individu akan mengevaluasi masalah tersebut dan membuat suatu perubahan dengan mencari solusi dari permasalahan yang dihadapi. Selanjutnya individu akan merancang suatu rencana yang efektif dan efisien. Setelah menemukan rencana yang matang dalam menghadapi masalah, individu akan melakukan tindakan yang tepat yang mengarah ke tujuan dan memodifikasi sikap sesuai dengan yang diinginkan. Pada tahap akhir individu akan mengukur efektif tidaknya rencana yang telah dibuat dan hasil yang didapat sesuai dengan yang diharapkan atau tidak. Dalam hal ini individu yang memiliki regulasi diri yang baik ketika mengalami permasalahan dalam penyesuaian diri, maka akan melakukan langkah-langkah dalam menyelesaikan permasalahannya.

Tingkat religiusitas yang dimiliki oleh santri juga menjadi faktor yang mempengaruhi penyesuaian diri di lingkungan pondok pesantren. Religiusitas adalah kemampuan yang dimiliki santri dalam memahami, menghayati, serta mengaplikasikan nilai-nilai agama yang dianutnya dalam kehidupan sehari-hari. Ketika santri mengalami konflik dengan teman pondok, atau mengalami frustasi dan ketegangan psikis yang disebabkan oleh hal lain maka konflik, frustasi dan ketengan psikis ini dapat berkurang dengan adanya religiusitas, karena religiusitas dapat memberikan suasana psikologis yang positif. Religiusitas mencerminkan kepemilikan nilai, keyakinan dan praktik-praktik keagamaan sehingga individu mampu memaknai kehidupan dengan arti yang mendalam, tujuan hidup dan stabilitas emosi yang jelas yang digunakan dalam menghadapi tuntutan dan perubahan yang terjadi dalam hidupnya (Jalaluddin, 2012).

Adapun dinamika psikologis hubungan antar konsep diri, regulasi diri, tingkat religiusitas dengan penyesuaian diri dapat digambarkan yaitu, 1) konsep diri yang terbentuk dari sudut pandang individu tentang gambaran dan penilaian tentang diri sendiri yang meliputi seluruh keyakinan, perasaan, dan kecenderungan seseorang dalam bersikap dan berperilaku serta mengingat segala hal yang telah diperoleh dari pengalaman membangun relasi dengan orang lain. Santri yang memiliki konsep diri yang positif akan membentuk penyesuaian diri yang tinggi. Hal ini karena santri baru 
mampu memenuhi aspek-aspek yang tercakup dalam konsep diri baik secara fisik, psikis, sosial maupun moral, sehingga santri mampu hidup dan berinteraksi seefektif mungkin di lingkungan pondok. Hal senada dikemukakan pada hasil penelitian Astuti, dkk (2014); 2) Regulasi diri terbentuk dari beberapa aspek yaitu pemikiran sebelumnya, kontrol kehendak, dan refleksi diri. Ketika individu mampu merencanakan dan menetapkan tujuan, mampu melihat kondisi sekitar, maka dengan mudah individu akan menerima kelebihan dan kekurangan dirinya sehingga tidak mengganggu proses penyesuaian dirinya. Hal ini didukung dengan pernyataan Schneider (dalam Asrori \& Ali, 2006) yang mengemukakan faktor-faktor yang dapat mempengaruhi penyesuaian diri adalah kondisi fisik, kepribadian, proses belajar, lingkungan dan agama. 3) tingkat religiusitas yang dimiliki individu mencakup lima dimensi yaitu keyakinan, praktik ibadah, penghayatan, pengatahuan agama dan pengamalan. Hal ini di dukung dengan pendapat Glock (Rakhmat, 2005) bahwa religiusitas yang dimiliki individu sebenarnya mengarah pada pelaksanaan keagamaan yang berupa penghayatan dan pembentukan komitmen, sehingga lebih merupakan proses internalisasi nilai-nilai agama untuk kemudian diamalkan dalam perilaku sehari-hari.

\section{Kesimpulan}

Berdasarkan hasil uji statistik menggunakan analisis regresi linier berganda didapatkan data bahwa nilai $\mathrm{F}=15.358$ dengan nilai $\mathrm{Rx}_{1 \times 2} \mathrm{X}_{2}-\mathrm{y}$ sebesar 0,614 dan nilai $\mathrm{p}=0,000(\mathrm{p}<0,05)$ sehingga dapat disimpulkan bahwa $\mathrm{Ha}=$ diterima dan $\mathrm{Ho}=$ ditolak. Hal ini berarti bahwa ada hubungan antara konsep diri, regulasi diri dan tingkat religiusitas dengan penyesuaian diri pada santri Pondok Pesantren Al Berr Pasuruan.

\section{Daftar Pustaka}

Ancok, D., \& Suroso, F. N. (1994). Psikologi Islami. Yogyakarta: Pustaka Pelajar.

Asrori, M., \& Ali, M. (2006). Psikologi Remaja: Perkembangan Peserta Didik. Jakarta: PT Bumi Aksara. Astuti, A. P., Rosra, M., \& Zulkifli, R. R. (2014). Hubungan Konsep Diri Positif dengan Penyesuaian Diri Mahasiswa FKIP Unila Luar Lampung. ALIBKIN : Jurnal Bimbingan Konseling. Volume 3 Nomor 4 Tahun $2014 . \quad$ Diunduh dari http://jurnal.fkip.unila.ac.id/index.php/ALIB/article/view/9583

Baron, R. A, \& Byrne, D, E,.(2004). Social Psychology (Loth Ed).USA : Person

Berzonsky, M.D. (1981). Adolescent Development. New York: Mc. Millan Publishing Co, Inc.

Calhoun, J. F. \& Acocella, J. R. (2010). Psikologi Tentang Penyesuaian dan Hubungan Kemanusiaan (Terjemahan oleh Satmoko, R.S.) edisi ketiga. Semarang : Penerbit IKIP Semarang.

Furhman, B.S. (1990). Adolescent. Illinois: Scoot Foresman and Company.

Ghufron, M.N., \& Risnawita, R. (2014). Teori-teori Psikologi, Yogyakarta, Ar-Ruzz Media.

Irene, S, Sitorus, S, Warsito, H. (2013). Perbedaan Tingkat Kemandirian Dan Penyesuaian Diri Mahasiswa Perantau Suku Batak Ditinjau Dari Jenis Kelamin. Character : Jurnal Penelitian Psikologi. Volume 01 Nomor 02, tahun 2013.

Jalaluddin. (2012). Psikologi Agama. Jakarta: Raja Grafindo Persada.

Nawawi. (2019, 29 Juni . Tangis Wali Santri Saat Anaknya Tidak Betah di Pesantren. diunduh dari https://www.nu.or.id/post/read/108010/tangis-wali-santri-saat-anaknya-tidak-betah-di-pesantren

Neal, D. \& Carey, K. (2005). A Follow-Up Psychometric Analysis Of The Self-Regulation Questionnaire. Psychology of Addictive Behaviors, 19(4), 414-422.

Nurhasyanah. (2012). Faktor-faktor yang Mempengaruhi Penerimaan Diri Pada Wanita Infertilitas. Jurnal Penelitian dan Pengukuran Psikologi. Vol,1. No,1.Oktober 2012.

Pemerintah Republik Indonesia. (2003). UNDANG-UNDANG REPUBLIK INDONESIA NOMOR 20 TAHUN 2003 TENTANG SISTEM PENDIDIKAN NASIONAL. diunduh dari https://pmpk.kemdikbud.go.id/assets/docs/UU_2003_No_20_-_Sistem_Pendidikan_Nasional.pdf

Pintrich, P. R. (2003). A motivational science perspective on the role of student motivation in learning and teaching contexts. Journal of Educational Psychology, 95(4), 667-686.

Rakhmat, J. (2005). Psikologi Agama Sebuah Pengantar. Bandung: Mizan 
Siregar, R. J. (2003). Diri Pribadi (Self) dan Kaitannya dengan Penyesuaian Diri : Telaah Mengenai Pengaruh Antar Komponen Diri Pribadi dan Kaitannya dengan Upaya Menghadapi Kehidupan Sosial di abad 21 Pada Mahasiswa UNPAD. Universitas Indonesia. Jakarta.

Widjaja. (2014). Hubungan Lokus Kontrol Internal dengan Regulasi Diri pada Mahasiswa Sekolah Tinggi Agama Budha (STAB) Maha Prajna Jakarta. Jurnal Psiko Edukasi. Volume 2 Nomor 2 Tahun 2014. 